\title{
Modelling groundwater contamination above a potential nuclear waste repository in the Columbia River Basalt, USA
}

\author{
Michael O. Schwartz ${ }^{1}$
}

Received: 11 February 2018 / Accepted: 16 June 2018 / Published online: 23 June 2018

(c) The Author(s) 2018

\begin{abstract}
Potential groundwater contamination above the one-time candidate repository for high-level nuclear waste in the Columbia River Basalt (CRB), USA, is evaluated in a flow-transport model with 260,895 elements for a period of 1 million years. The hydrogeologic database originates from the Basalt Waste Isolation Project, which ended in 1987, giving way to the Yucca Mountain project. The CRB data have been scanned recently with the object of finding a storage site for natural gas and a sequestration site for $\mathrm{CO}_{2}$. However, the impact on the nuclear issue in the USA or other countries with similar large floodbasalt provinces has never been evaluated since the suspension of the project. The peak radioactive dose predicted for a potential repository in the CRB is at least eight orders of magnitude lower than the US generic regulatory limit $(0.15 \mathrm{mS} / \mathrm{a})$ even for the most pessimistic scenario.
\end{abstract}

Keywords Nuclear-waste disposal $\cdot$ Basalt $\cdot$ Groundwater contamination $\cdot$ USA

\section{Introduction}

Flood basalt has extraordinary characteristics that make it a prime candidate for a radioactive-waste disposal site. Flood basalt is less common than granite or shale, which are the host rocks of repositories under construction. The best studied occurrence of flood basalt is the Columbia River Basalt (CRB), in Washington, Oregon and Idaho; USA (Fig. 1). A huge amount of geoscientific data have been collected (reviewed in Reidel et al. 2002). This occurred mainly in the period from 1968 to 1987 when the $1200 \mathrm{~km}^{2}$ Hanford Site was investigated with the object of identifying a disposal site. The work was suspended, because Yucca Mountain, Nevada, was designated by the "Waste Policy Act as Amended" (DOE 2004) in 1987 to be the deep geological repository for burnt fuel and other types of highlevel nuclear waste. On April 14, 2011, the US government decreed to stop funding the Yucca Mountain project. Since then, the US Department of Energy (DOE) has not conducted any site-specific investigations but only generic studies, most of them related to crystalline rocks.

Michael O. Schwartz

mathgeol@yahoo.de

1 MathGeol, Postfach 101204, 30833 Langenhagen, Germany
In terms of exploratory drilling density, the CRB study area $\left(1200 \mathrm{~km}^{2}\right)$ and Yucca Mountain study area $\left(1350 \mathrm{~km}^{2}\right)$ are equivalent. However, the CRB project lacks underground workings, whereas the Yucca Mountain project has an exploratory adit.

Prior to the suspension of the CRB project, there have been some rudimentary approaches to $2 \mathrm{D}$ modelling of groundwater flow. The results are contradictory and not suitable for a performance assessment (Duguid and Kowall 1981; DOE 1988). With the development of 3D flow-transport parallel codes, the situation has changed.

This paper bridges the time gap between data collection and advent of suitable hard and software. The high hydraulic gradients remain a challenge in terms of numerical stability but some modern codes can cope with these. The study is the first of its kind. Although it is a case study, most of the findings should apply to potential repositories located in basalt in other parts of the world. A possible exception is the groundwater chemistry. The CRB groundwater has a high $\mathrm{pH}$, averaging 9.4, which allows copper-shielded waste containers to be in thermodynamic equilibrium with groundwater, thus minimizing the risk of damage by corrosion. 


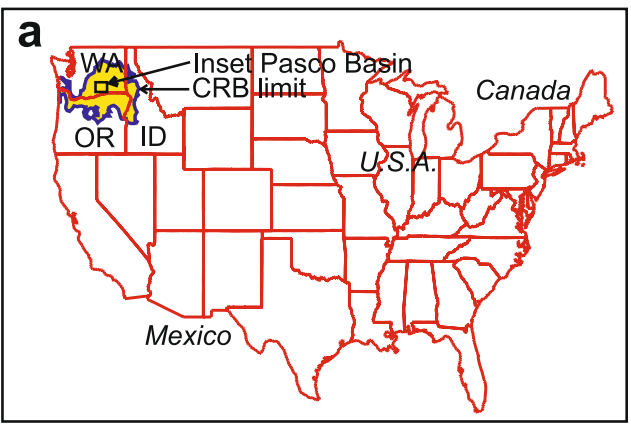

b
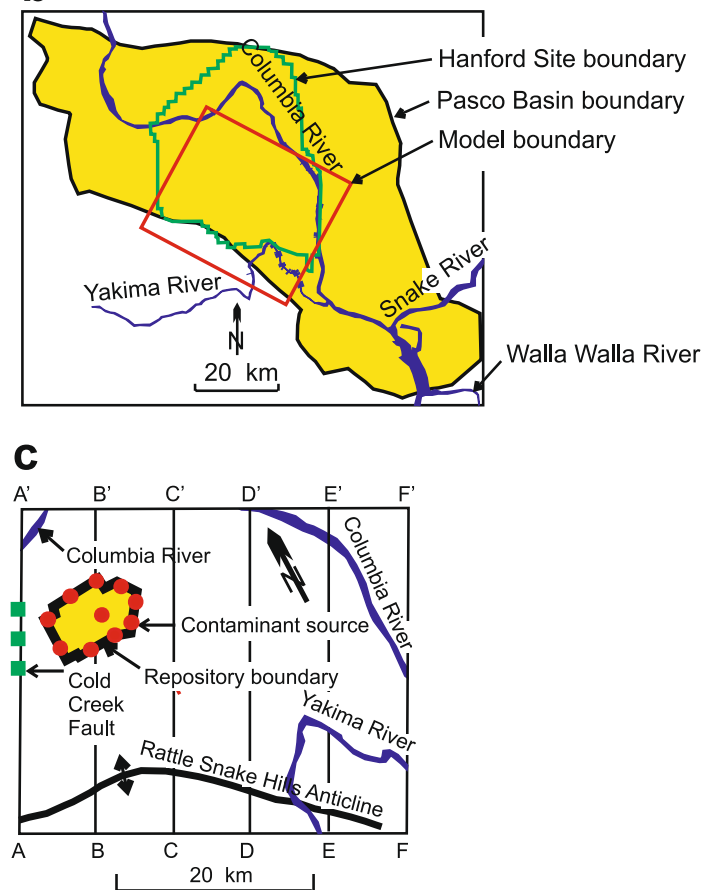

Fig. 1 a Location of the Columbia River Basalt (CRB), USA. b Pasco Basin with the location of the model area. $\mathbf{c}$ Map of the model area and traces of cross sections (Fig. 4)

\section{Study area}

\section{Hydrogeological database}

The $1226-\mathrm{km}^{2}$ model is located in the Pasco Basin in the central part of the CRB. An irregular cover of Quaternary through Upper Tertiary sedimentary deposits overlies the basaltic rocks. The major subdivisions of the CRB are the Saddle Mountains Basalt Formation (isotopic age 6-13 ma), Wanapum Basalt Formation (14.5-15.6 ma), Grande Ronde Basalt Formation (15.6-16.5 ma), and Imnaha Basalt Formation (17.5 ma). Stratigraphically, the model comprises the Quaternary and the Schwana Sequence of the Grande Ronde Basalt Formation (Table 1).
The CRB has been subjected to folding. The best documented tectonic feature is the high-amplitude fold of the Rattlesnake Hills. The topographic high of the model lies in the anticlinal area (Figs. 1,2). This coincides more or less with the maximum water-level at $360 \mathrm{~m}$ a.s.l. (Whiteman et al. 1994). The topographic low is represented by the Columbia River valley (lowest water-level at $110 \mathrm{~m}$ a.s.1.).

\section{Hydraulic properties}

Reidel et al. (2002) summarised the results of field tests for the interior of basalt flows (22 measurements), flow tops (157) and interbeds (48). Most tests consisted of single borehole tests conducted in boreholes that were progressively drilled and tested. Some tests were conducted in existing boreholes in which test zones were isolated using straddle packers.

The hydraulic conductivity of the basalt interiors ranges from $10^{-16}$ to $10^{-10} \mathrm{~m} / \mathrm{s}$ (Fig. 3). The maximum value, approximately corresponding to a permeability of $10^{-17} \mathrm{~m}^{2}$, is used for the base-case calculations. The individual interbeds and underlying flow tops are combined to single individual units. These have a permeability of $10^{-15} \mathrm{~m}^{2}$, corresponding to the median for the flow tops in the Grande Ronde Basalt Formation. The overburden only occupies a minimal portion of the model and hardly influences the contaminant transport calculations. For the sake of numerical stability, the overburden has the same hydraulic properties as those of the interbeds/flow tops.

The effective porosity, which refers to the interconnected void space, is set at 0.15 for the interbeds/flow tops in agreement with the modelling of gas storage capacity of the CRB (Reidel et al. 2002). The porosity of the flow interiors is set at 0.005 .

\section{The repository}

According to the latest layout, the CRB repository (Hanford Reference Repository) should be located in the Sentinel Bluffs Sequence of the Grande Ronde Basalt Formation at a depth of $900 \mathrm{~m}$ (DOE 1988). An earlier version has an additional option with the Umtanum Flow of the Schwana Sequence at a depth of 1100 m (DOE 1982). The Nuclear Waste Policy Act of 1982 specifies that the first US repository cannot exceed the equivalent of 70,000 MTHM (metric tons of heavy metal, including uranium and other radioactive heavy metals) until a second repository becomes operational. The statuary limit is still valid today and corresponds to 11,629 waste containers (Table 2; DOE 2007a). The horizontal dimensions of the repository are $9000 \mathrm{~m} \times 6000 \mathrm{~m}$ (DOE 1982). 
Table 1 Hydrostratigraphic units and hydraulic properties of the Columbia River Basalt (CRB)

\begin{tabular}{|c|c|c|c|c|c|c|c|}
\hline Formation & Member/sequence & $\begin{array}{l}\text { Sediment/basalt } \\
\text { stratigraphy }\end{array}$ & Rock type & Thickness (m) & $\begin{array}{l}\text { Base-case } \\
\text { permeability } \\
\left(\mathrm{m}^{2}\right)\end{array}$ & Porosity (-) & Repository horizon \\
\hline \multirow[t]{2}{*}{ Ringold } & & Upper Ringold & $\mathrm{S}$ & 50 & $10^{-15}$ & 0.15 & \\
\hline & & Lower Ringold & S & 17 & $10^{-15}$ & 0.15 & \\
\hline \multirow{7}{*}{$\begin{array}{l}\text { Saddle Mountains } \\
\text { Basalt }\end{array}$} & Elephant mountain & & B & 50 & $10^{-17}$ & 0.005 & \\
\hline & Pomona & & FT & 17 & $10^{-15}$ & 0.15 & \\
\hline & & & B & $45-55$ & $10^{-17}$ & 0.005 & \\
\hline & Esquatzel & & FT & 17 & $10^{-15}$ & 0.15 & \\
\hline & & & B & $45-55$ & $10^{-17}$ & 0.005 & \\
\hline & Umatilla & & FT & 17 & $10^{-15}$ & 0.15 & \\
\hline & & & B & $45-55$ & $10^{-17}$ & 0.005 & \\
\hline \multirow[t]{12}{*}{ Wanapum Basalt } & Priest rapids & & FT & 17 & $10^{-15}$ & 0.15 & \\
\hline & & & B & $45-55$ & $10^{-17}$ & 0.005 & \\
\hline & Roza & & FT & 17 & $10^{-15}$ & 0.15 & \\
\hline & & & B & $45-55$ & $10^{-17}$ & 0.005 & \\
\hline & Frenchman springs & Sentinel gap flow & FT & 17 & $10^{-15}$ & 0.15 & \\
\hline & & & B & $45-55$ & $10^{-17}$ & 0.005 & \\
\hline & & Sand hollow flow & FT & 17 & $10^{-15}$ & 0.15 & \\
\hline & & & B & $45-55$ & $10^{-17}$ & 0.005 & \\
\hline & & Gingko flow & FT & 17 & $10^{-15}$ & 0.15 & \\
\hline & & & B & $45-55$ & $10^{-17}$ & 0.005 & \\
\hline & & Pallouse falls flow & FT & 17 & $10^{-15}$ & 0.15 & \\
\hline & & & B & $45-55$ & $10^{-17}$ & 0.005 & \\
\hline \multirow[t]{16}{*}{ Grande Ronde Basalt } & Sentinel bluffs & Flow I & FT & 17 & $10^{-15}$ & 0.15 & \\
\hline & & & B & 50 & $10^{-17}$ & 0.005 & \\
\hline & & Rocky coulee flow & FT & 17 & $10^{-15}$ & 0.15 & \\
\hline & & & B & 50 & $10^{-17}$ & 0.005 & Sensitivity case \\
\hline & & Cohasset flow & FT & 17 & $10^{-15}$ & 0.15 & \\
\hline & & & B & 50 & $10^{-17}$ & 0.005 & \\
\hline & & McCoy Canyon flow & FT & 17 & $10^{-15}$ & 0.15 & \\
\hline & & & B & 50 & $10^{-17}$ & 0.005 & \\
\hline & Schwana & Umtanum flow & FT & 17 & $10^{-15}$ & 0.15 & \\
\hline & & & B & 50 & $10^{-17}$ & 0.005 & Base case \\
\hline & & Very high-Mg flow & FT & 17 & $10^{-15}$ & 0.15 & \\
\hline & & & B & 50 & $10^{-17}$ & 0.005 & \\
\hline & & Flow I & FT & 17 & $10^{-15}$ & 0.15 & \\
\hline & & & B & 50 & $10^{-17}$ & 0.005 & \\
\hline & & Flow II & FT & 17 & $10^{-15}$ & 0.15 & \\
\hline & & & B & 50 & $10^{-17}$ & 0.005 & \\
\hline
\end{tabular}

$S$ sediment, $B$ basalt interior, $F T$ flow tops/interbeds

There are various disposal schemes for the CRB repository. The latest studies indicate that copper-shielded waste containers emplaced in a bentonite buffer are the preferred option (Lutton et al. 1986). Thus, the CRB concept would be the equivalent to the KBS-3 scheme of the Scandinavian repositories under construction (SKB 2006). Accordingly, the containers are emplaced in deposition holes driven from deposition tunnels, which are connected to a nearly horizontal system of access and transport tunnels. The containers that host the waste have a 5 -cm-thick corrosion-resistant copper shell around an inner deformationresistant cast-iron canister; the containers are embedded in a $35-\mathrm{cm}$-thick bentonite buffer. 


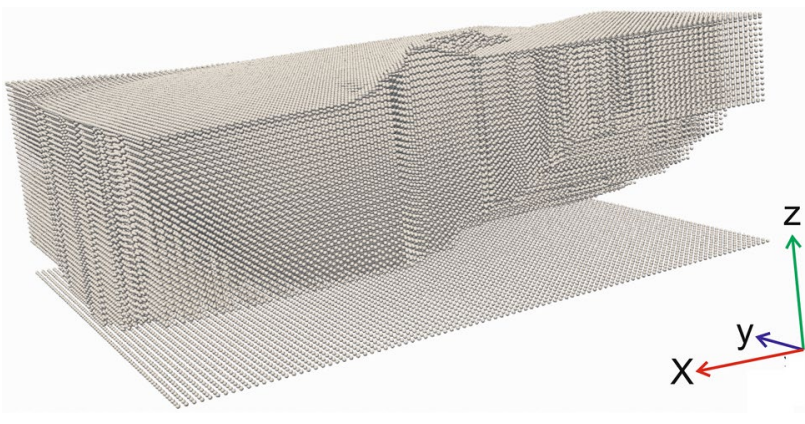

Fig. 2 Block diagram of the CRB model mesh showing nodal positions. Ten-fold vertical exaggeration ( $z$ direction)
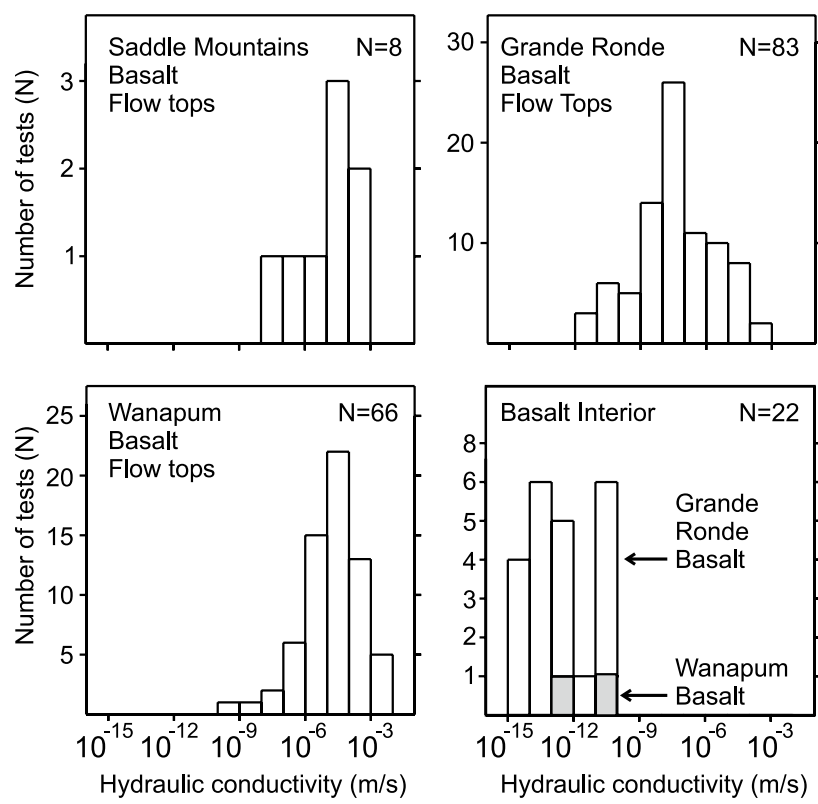

Fig. 3 Histograms showing the hydraulic conductivity $(\mathrm{m} / \mathrm{s})$ of the Saddle Mountains Basalt Formation, Wanapum Basalt Formation and Grande Ronde Basalt Formation of the Columbia River Basalt (CRB)

\section{Model setup}

\section{Geometry}

The model mesh calculated with WINGRIDDER (Pan 2007) has a total of 260,895 elements and a maximum of 37 layers. The mesh is irregular vertically and regular horizontally, and measures $38,800 \times 31,600 \times 1510 \mathrm{~m}$ (Figs. 2, 4). The nodal distance in the $\mathrm{x}$ and $\mathrm{y}$ directions is $400 \mathrm{~m}$. The top layer has nodal $z$ values representing the waterlevel (90-360 m a.s.l.; Fig. 5). The following layers have a thickness that roughly represents the thickness of the interior of the individual basalt flows (colonade/entablure), on the one hand, and flow tops (including interbeds), on the other hand. The bottom of the mesh is the $-1150-\mathrm{m}$ level.
The top layer, which serves to maintain constant temperature, pressure and salinity, exclusively consists of infinitevolume boundary elements $\left(10^{52} \mathrm{~m}^{3}\right)$. The bottom layer cells have a volume of $10^{12} \mathrm{~m}^{3}$. This volume is large enough for maintaining nearly constant temperature and salinity throughout the simulation period of one million years but simultaneously flexible enough to account for pressure adjustments. The volume of the remaining cells is calculated according to their nodal positions.

The water-level remains fixed in the base case (110-360 $\mathrm{m}$ a.s.l. range). Transient conditions are calculated in a sensitivity case, which simulates sea-level lowering. In the simulation year 50,000, the water-level changes from the $110-360 \mathrm{~m}$ range to the $90-360 \mathrm{~m}$ range, whereby the values above $170 \mathrm{~m}$ a.s.l. remain unchanged, because they have relatively little influence on contaminant transport. The transient condition corresponds to an increase in the hydraulic gradient by a factor of 1.33 in the domain with water-level values $<170 \mathrm{~m}$ a.s.l..

\section{Boundary conditions and initial conditions}

The infinite-volume elements $\left(10^{52} \mathrm{~m}^{3}\right)$ of the top layer, which impose Dirichlet conditions, have a pressure of $10^{5}$ $\mathrm{Pa}$, a temperature of $14^{\circ} \mathrm{C}$ and zero salinity. The large volume elements of the bottom layer $\left(10^{12} \mathrm{~m}^{3}\right)$ impose nearly Dirichlet conditions with respect to temperature $\left(64^{\circ} \mathrm{C}\right)$ and salinity $(0.0017$ mass fraction brine or 0.00042 mass fraction salt), but allow flexible pressure adjustments. The remaining layers have initial values along the gradients defined by the top and bottom layers, which are close to the presentday values. These boundary conditions and an initialisation pre-run with a high diffusivity of brine $\left(10^{-7} \mathrm{~m}^{2} / \mathrm{s}\right)$ allow suitable vertical gradients throughout the actual simulation with standard brine diffusivity $\left(10^{-9} \mathrm{~m}^{2} / \mathrm{s}\right)$, unless disturbed by radioactive heat sources.

The definition of the outer horizontal boundaries is straightforward on three sides of the model. They are treated as closed boundaries, because they are more or less aligned along natural boundaries: the Columbia River acts as discharge area NNE and ESE; and the Rattlesnake Hills act as drainage divide SSW (Figs. 1, 5).

Only a small section of the WNW boundary is well defined. This is the Cold Creek Fault, which acts as aquiclude. The potentiometric surface on the WNW side of the fault (i.e., outside the model area) is tens of meters above the potentiometric surface on the ESE side (i.e., inside the model area; Reidel et al. 2002, Fig. 3.4). Thus, the hydraulic gradient in the direction at right angle to the fault (WNW-ESE direction) is near zero for a length of $15 \mathrm{~km}$. This is the area occupied by the potential repository (Fig. 5). 
Table 2 Setup of the Columbia River Basalt (CRB) model

\section{General properties}

Simulation period (a)

Rock grain density $\left(\mathrm{kg} / \mathrm{m}^{3}\right)$

Rock grain specific heat $\left(\mathrm{J} / \mathrm{kg}{ }^{\circ} \mathrm{C}\right)$

Formation heat conductivity $\left(\mathrm{W} / \mathrm{m}{ }^{\circ} \mathrm{C}\right)$

Number of simultaneous contaminant sources (-)

Repository

Capacity (MTHM) ${ }^{\mathrm{a}}$

Number of waste containers (-)

Depth (m)

In-situ temperature $\left({ }^{\circ}\right)$

Initial inventory

Am-241 (Bq)

Cs-135 (Bq)

I-129 (Bq)

$\mathrm{Np}-237(\mathrm{~Bq})$

Pa-231 (Bq)

Pu-240 (Bq)

$\mathrm{Pu}-242(\mathrm{~Bq})$

Se-79 (Bq)

Tc-99 (Bq)

Th-230 (Bq)

$\mathrm{U}-233$ (Bq)

$\mathrm{U}-234(\mathrm{~Bq})$

$\mathrm{U}-236(\mathrm{~Bq})$

$\mathrm{U}-238(\mathrm{~Bq})$

Half-life

Am-241 (a)

Cs-135 (a)

I-129 (a)

Np-237 (a) ${ }^{\text {b }}$

Pa-231 (a)

Pu-240 (a) ${ }^{\mathrm{c}}$

Pu-242 (a) ${ }^{\mathrm{d}}$

Se-79 (a)

Tc-99 (a)

Th-230 (a) ${ }^{\mathrm{e}}$

U-233 (a) ${ }^{\text {b }}$

U-234 (a) ${ }^{\mathrm{e}}$

U-236 (a) ${ }^{\mathrm{c}}$

U-238 (a) ${ }^{\mathrm{d}}$

Distribution coefficient

Cs-135 (mL/g)

I-129 (mL/g)

$\mathrm{Np}-237(\mathrm{~mL} / \mathrm{g})$

Pa-231 (mL/g)

$\mathrm{Pu}-240(\mathrm{~mL} / \mathrm{g})$

$\mathrm{Pu}-242(\mathrm{~mL} / \mathrm{g})$

Se-79 $(\mathrm{mL} / \mathrm{g})$

Tc-99 (mL/g)
$1,000,000$

2800

950

2.3

1,10

70,000

11,629

900 [Sentinel bluffs sequence] 1100 [Umtanum flow]

50 [Sentinel bluffs sequence]

57 [Umtanum flow]

$8.65 \times 10^{18}$

$1.56 \times 10^{15}$

$9.55 \times 10^{13}$

$1 \times 10^{15}$

$1.01 \times 10^{13}$

$1.44 \times 10^{18}$

$6.40 \times 10^{15}$

$2.15 \times 10^{14}$

$4.02 \times 10^{16}$

$1.01 \times 10^{12}$

$1.10 \times 10^{14}$

$3.41 \times 10^{15}$

$7.67 \times 10^{14}$

$9.04 \times 10^{14}$

$4.33 \times 10^{2}$

$2.3 \times 10^{6}$

$1.57 \times 10^{7}$

$2.14 \times 10^{6}$

$3.28 \times 10^{4}$

$6.56 \times 10^{3}$

$3.75 \times 10^{5}$

$2.9 \times 10^{5}$

$2.13 \times 10^{5}$

$7.54 \times 10^{4}$

$1.59 \times 10^{5}$

$2.46 \times 10^{5}$

$2.34 \times 10^{7}$

$4.47 \times 10^{9}$

$-$

200

1000

20

20

8

29 
Table 2 (continued)

\begin{tabular}{|c|c|}
\hline Th-230 (mL/g) & 5000 \\
\hline $\mathrm{U}-233(\mathrm{~mL} / \mathrm{g})$ & 40 \\
\hline $\mathrm{U}-234(\mathrm{~mL} / \mathrm{g})$ & 40 \\
\hline U-236 (mL/g) & 40 \\
\hline $\mathrm{U}-238(\mathrm{~mL} / \mathrm{g})$ & 40 \\
\hline \multicolumn{2}{|l|}{ Diffusivity } \\
\hline Cs-135 $\left(\mathrm{m}^{2} / \mathrm{s}\right)$ & $9 \times 10^{-13}$ \\
\hline $\mathrm{I}-129\left(\mathrm{~m}^{2} / \mathrm{s}\right)$ & $8 \times 10^{-15}$ \\
\hline $\mathrm{Np}-237\left(\mathrm{~m}^{2} / \mathrm{s}\right)$ & $4 \times 10^{-14}$ \\
\hline $\mathrm{Pa}-231\left(\mathrm{~m}^{2} / \mathrm{s}\right)$ & $4 \times 10^{-14}$ \\
\hline $\mathrm{Pu}-240\left(\mathrm{~m}^{2} / \mathrm{s}\right)$ & $4 \times 10^{-14}$ \\
\hline $\mathrm{Pu}-242\left(\mathrm{~m}^{2} / \mathrm{s}\right)$ & $4 \times 10^{-14}$ \\
\hline $\operatorname{Se}-79\left(\mathrm{~m}^{2} / \mathrm{s}\right)$ & $4 \times 10^{-14}$ \\
\hline Tc-99 $\left(\mathrm{m}^{2} / \mathrm{s}\right)$ & $4 \times 10^{-14}$ \\
\hline Th-230 $\left(\mathrm{m}^{2} / \mathrm{s}\right)^{\mathrm{e}}$ & $4 \times 10^{-14}$ \\
\hline $\mathrm{U}-233\left(\mathrm{~m}^{2} / \mathrm{s}\right)$ & $4 \times 10^{-14}$ \\
\hline $\mathrm{U}-234\left(\mathrm{~m}^{2} / \mathrm{s}\right)$ & $4 \times 10^{-14}$ \\
\hline $\mathrm{U}-236\left(\mathrm{~m}^{2} / \mathrm{s}\right)$ & $4 \times 10^{-14}$ \\
\hline $\mathrm{U}-238\left(\mathrm{~m}^{2} / \mathrm{s}\right)$ & $4 \times 10^{-14}$ \\
\hline \multicolumn{2}{|l|}{ Solubility } \\
\hline Cs-135 (M/L) & Unlimited \\
\hline $\mathrm{I}-129(\mathrm{M} / \mathrm{L})$ & Unlimited \\
\hline $\mathrm{Np}-237(\mathrm{M} / \mathrm{L})$ & $10^{-15}$ \\
\hline $\mathrm{Pa}-231(\mathrm{M} / \mathrm{L})$ & $3 \times 10^{-7}$ \\
\hline $\mathrm{Pu}-240(\mathrm{M} / \mathrm{L})$ & $10^{-9}$ \\
\hline $\mathrm{Pu}-242(\mathrm{M} / \mathrm{L})$ & $10^{-9}$ \\
\hline Se-79 (M/L) & $10^{-15}$ \\
\hline Tc-99 (M/L) & $10^{-12}$ \\
\hline Th-230 (M/L) & $10^{-9}$ \\
\hline $\mathrm{U}-233(\mathrm{M} / \mathrm{L})$ & $10^{-8}$ \\
\hline U-234 (M/L) & $10^{-8}$ \\
\hline $\mathrm{U}-236(\mathrm{M} / \mathrm{L})$ & $10^{-8}$ \\
\hline $\mathrm{U}-238(\mathrm{M} / \mathrm{L})$ & $10^{-8}$ \\
\hline \multicolumn{2}{|l|}{ Release fraction } \\
\hline Cs-135 (-) & 0.13 \\
\hline I-129 (-) & 0.13 \\
\hline Np-237 (-) & 0.0001 \\
\hline $\mathrm{Pa}-231(-)$ & 0.001 \\
\hline $\mathrm{Pu}-240(-)$ & 0.001 \\
\hline $\mathrm{Pu}-242(-)$ & 0.001 \\
\hline $\mathrm{Se}-79(-)$ & 0.0001 \\
\hline Tc-99 (-) & 0.0001 \\
\hline Th-230 (-) & 0.001 \\
\hline U-233 (-) & 0.001 \\
\hline U-234 (-) & 0.001 \\
\hline U-236 (-) & 0.001 \\
\hline U-238 (-) & 0.001 \\
\hline \multicolumn{2}{|l|}{ Biodose conversion factor } \\
\hline Cs-135 (Sv/a:Bq/m³) & $1.45 \times 10^{-8}$ \\
\hline $\mathrm{I}-129\left(\mathrm{~Sv} / \mathrm{a}: \mathrm{Bq} / \mathrm{m}^{3}\right)$ & $1.29 \times 10^{-7}$ \\
\hline Np-237 (Sv/a:Bq/m³) & $2.47 \times 10^{-7}$ \\
\hline $\mathrm{Pa}-231\left(\mathrm{~Sv} / \mathrm{a}: \mathrm{Bq} / \mathrm{m}^{3}\right)$ & $2.44 \times 10^{-6}$ \\
\hline
\end{tabular}


Table 2 (continued)

\begin{tabular}{|c|c|}
\hline $\mathrm{Pu}-240$ (Sv/a:Bq/m³) & $9.51 \times 10^{-7}$ \\
\hline $\mathrm{Pu}-242\left(\mathrm{~Sv} / \mathrm{a}: \mathrm{Bq} / \mathrm{m}^{3}\right)$ & $9.07 \times 10^{-7}$ \\
\hline Se-79 (Sv/a:Bq/m³) & $2.42 \times 10^{-8}$ \\
\hline Tc-99 (Sv/a:Bq/m³) & $1.12 \times 10^{-9}$ \\
\hline Th-230 (Sv/a:Bq/m³) & $1.08 \times 10^{-6}$ \\
\hline U-233 (Sv/a:Bq/m³) & $8.97 \times 10^{-8}$ \\
\hline $\mathrm{U}-234$ (Sv/a:Bq/m³) & $8.19 \times 10^{-8}$ \\
\hline $\mathrm{U}-236\left(\mathrm{~Sv} / \mathrm{a}: \mathrm{Bq} / \mathrm{m}^{3}\right)$ & $7.67 \times 10^{-8}$ \\
\hline $\mathrm{U}-238$ (Sv/a:Bq/m³) & $7.87 \times 10^{-8}$ \\
\hline
\end{tabular}

${ }^{a}$ Metric tons heavy metal (uranium and other radioactive heavy metal)

${ }^{\mathrm{b}}$ Decay sequence: Am-241, Np-237, U-233

${ }^{c}$ Decay sequence: $\mathrm{Pu}-240, \mathrm{U}-236$

${ }^{\mathrm{d}}$ Decay sequence: $\mathrm{Pu}-242, \mathrm{U}-238$

e Decay sequence: U-234, Th-230 (U-234 diffusivity used for Th-230)

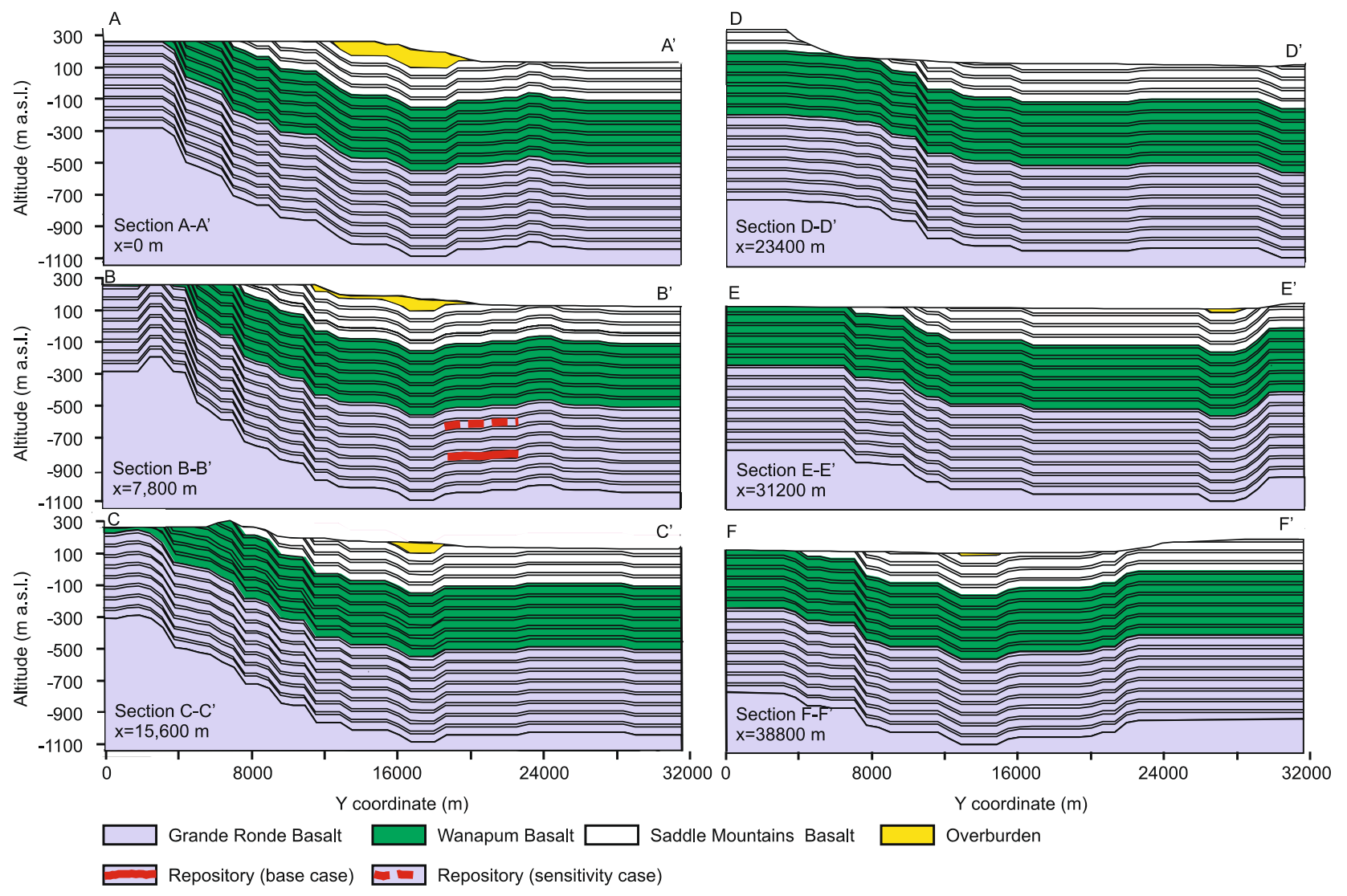

Fig. 4 Vertical cross sections of the CRB model

There are not enough data that allow to define the remaining part of the WNW boundary either as closed or open. As a consequence, the whole of the WNW boundary is treated as closed to avoid unnecessary bias. This has little practical consequences. However, it must be kept in mind that this boundary definition is an idealization and the actual shape of the contaminant plume would have more irregularities on 


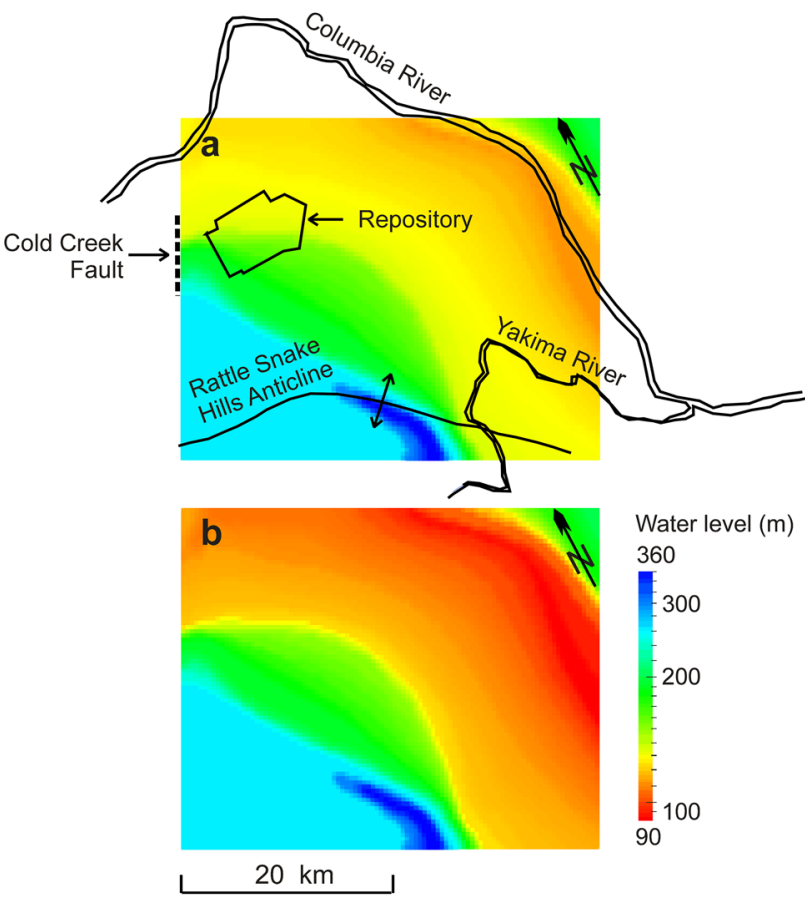

Fig. 5 a Present-day water level of the base case. b Water level in the year 50,000 (sensitivity case only)

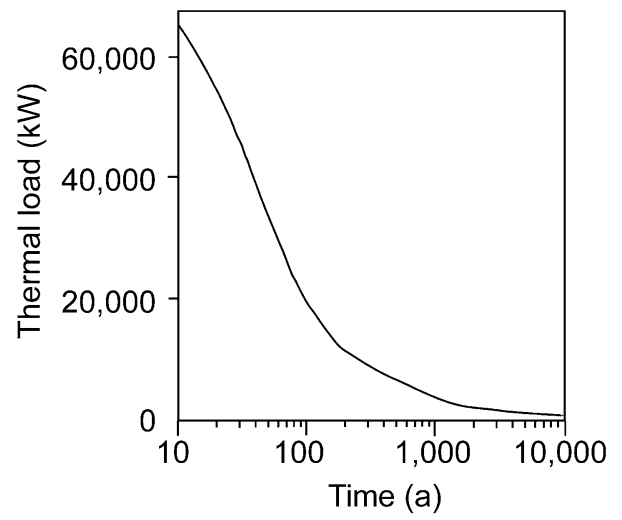

Fig. 6 Repository-wide thermal load (kW) (DOE 2008a)

its WNW side than shown in the figures of "Radionuclide transport".

Time-dependent Neumann boundary conditions that allow for heat production of the nuclear waste are imposed on all cells in the $9000 \times 6000 \mathrm{~m}$ repository area of the Sentinel Bluffs Sequence or Umtanum Flow of the Schwana Sequence. The heat production of the radioactive waste (Fig. 6; DOE 2008a) is divided by 55, which is the number of canisters divided by the number of repository cells, and is then used as heat-generation data for the individual cell.

Furthermore, time-dependent Neumann boundary conditions that allow for contaminant injection (Fig. 7) are imposed on one cell in the central repository area (base case) and additional nine cells on the periphery of the repository (sensitivity case). The injection rate " $R_{i}$ " for the radionuclide " $i$ " (Bq/a) in the simulation year " $n$ " is calculated with the simplification that the fraction of the inventory released per year remains constant during the simulation period:

$R_{i}=\frac{I_{i}}{N} \times\left(1-\frac{F_{i}}{10^{6}-s}\right)^{n-s} \times\left(F_{i} \times \frac{1}{10^{6}-s}\right)$

with " $I_{i}$ " being the inventory of the radionuclide " $i$ ", " $F$ " being the fraction of the radionuclide " $i$ " released until the end of the simulation period ( 1 million years), " $s$ " being the year in which the radionuclide release starts (simulation year 200), and " $N$ " being the number of canisters $(11,629)$. A conservative approach is used for defining the release fraction, based on data of DOE (2008b):

- $F_{i}=0.13$ for radionuclides without solubility limits.

- $F_{i}=0.001$ for radionuclides with high solubility limits.

- $F_{i}=0.0001$ for radionuclides with low solubility limits.

Solubility limits for 10 radionuclides out of a total of 13 are provided by Salter and Jacobs (1982) together with distribution coefficients for CRB groundwater. The missing data (I-129, Pa-231 and Th-230) are taken from a compilation for low-salinity granite groundwater, together with diffusivities for all radionuclides (Table 2; Lindgren and Lindström 1999).

\section{Computer code}

TOUGHREACT version 3 is a numerical simulation programme for chemically reactive non-isothermal flows of multi-phase fluids in porous and fractured media (Xu et al. 2014). The programme was developed by introducing reactive chemistry into the multi-phase flow code TOUGH2 (Pruess et al. 1999). The governing equations are discretised using integral finite difference for space and fully implicit first-order finite difference in time. All simulations of this study are performed with the EOS7 module, which treats the aqueous phase as a mixture of water and brine. The ECO2N module, which treats the aqueous phase as a mixture of water and salt, fails at initialisation but would be suitable for the actual simulation.

Theoretically, it is possible to use the EOS7R module of the other members of the TOUGH2 family of codes (including iTOUG2; Finsterle 2000, and TOUGH2-MP; Zhang et al. 2008) for the non-reactive transport simulations. However, the convergence behaviour of the EOS7R module in all versions of the TOUGH 2 code is by far inferior to that of the EOS7 module of TOUGHREACT version 
Fig. 7 Annual near-field release of radionuclides $(\mathrm{Bq} / \mathrm{a})$ from one defective waste container from year 200 to year $1,000,000$

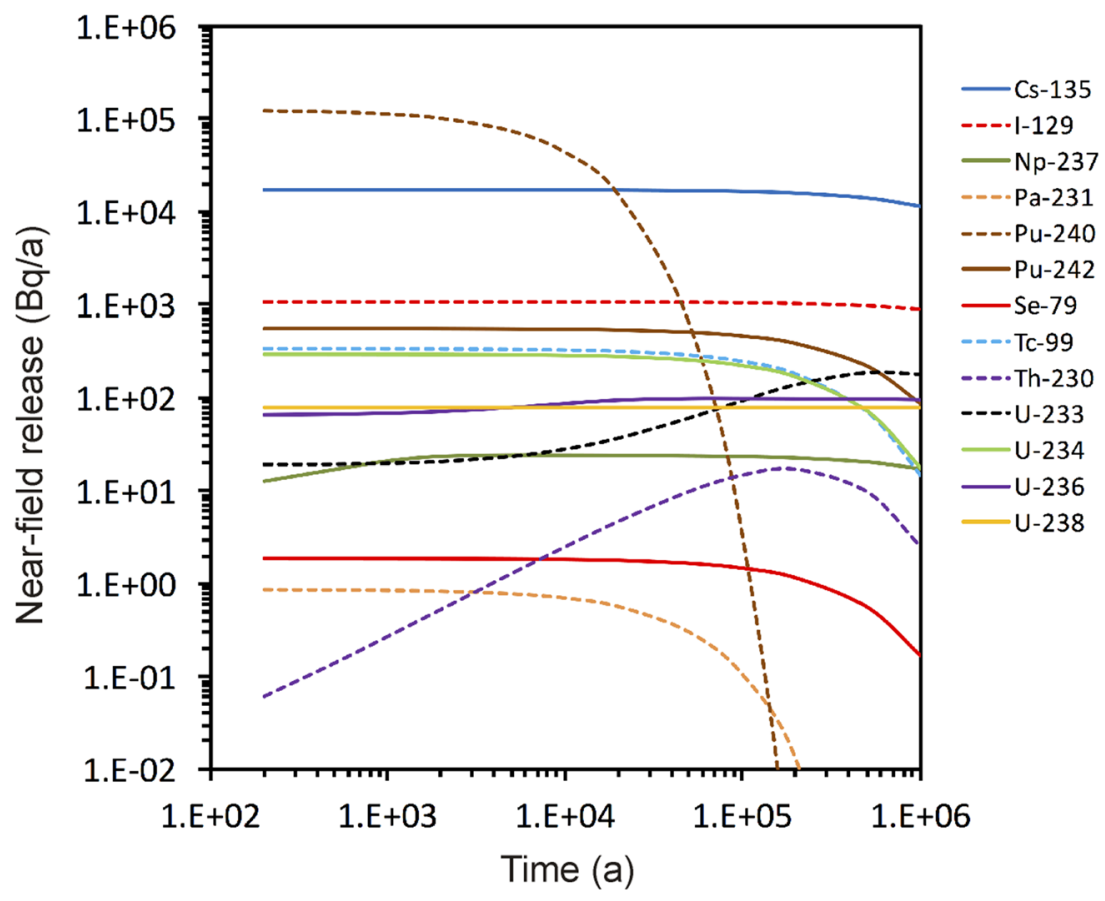

3. The FEHM code (Zyvoloski et al. 2011) has excellent convergence behaviour, but is too slow for long simulation periods and large models.

\section{Radionuclide transport}

The near-field base case assumes that one canister randomly chosen in the repository layout has a production defect. The variability of the possible contaminant plumes is depicted by selecting one source (base case) and nine additional sources (sensitivity case) at the centre and the periphery of the repository, respectively (Fig. 1c). The plumes emanating from the remainder of the canister locations would be intermediate between these geometric extremes (not calculated).

The radioactive dose " $D$ " (Sv/a) uses the biodose conversion factor (BDCF), representing the all-pathway dose (DOE $2007 b$ ). The future radiation dose to a hypothetical "reasonably maximally exposed individual" (RMEI) considers the most important exposure pathways:

- water intake;

- radiation exposure to contaminated soil;

- inhalation of radioactive particles and gases;

- consumption of contaminated plants;

- consumption of contaminated animal product foodstuff.

The dose is calculated according to the equation:

$$
D=\sum X_{i} B_{i}
$$
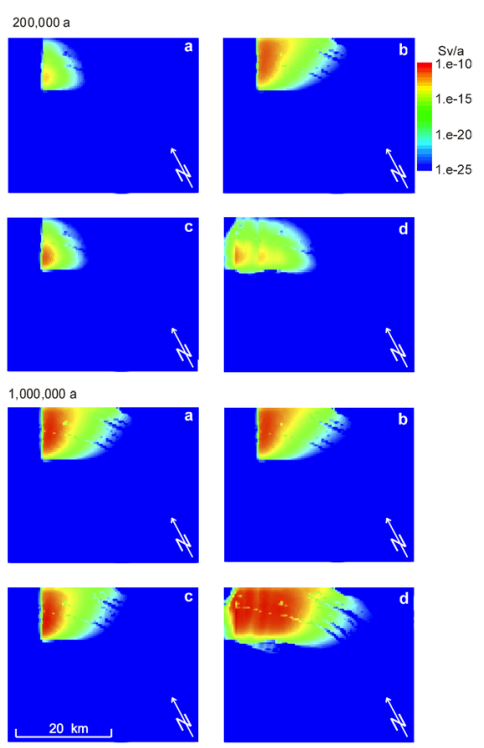

Fig. 8 Maps of the second topmost layer of the CRB model with fixed water-level showing the radioactive dose (Sv/a) in the simulation year 200,000 and 1,000,000. a Base case with 1 defective canister. b Sensitivity case 1 with base-case permeabilities multiplied by 10 as well as base-case repository depth and 1 defective canister. c Sensitivity case 2 with base-case repository depth decreased by $200 \mathrm{~m}$ as well as base-case permeabilities and 1 defective canister. d Sensitivity case 3 with 10 defective canisters as well as base-case permeabilities and base-case repository depth

where " $X_{i}$ " is the concentration $(\mathrm{Bq} / \mathrm{L})$ of the radionuclide " $i$ " in the second topmost cell and " $B_{i}$ " is the BDCF (Sv/a:Bq/L) of the radionuclide " $i$ ". 


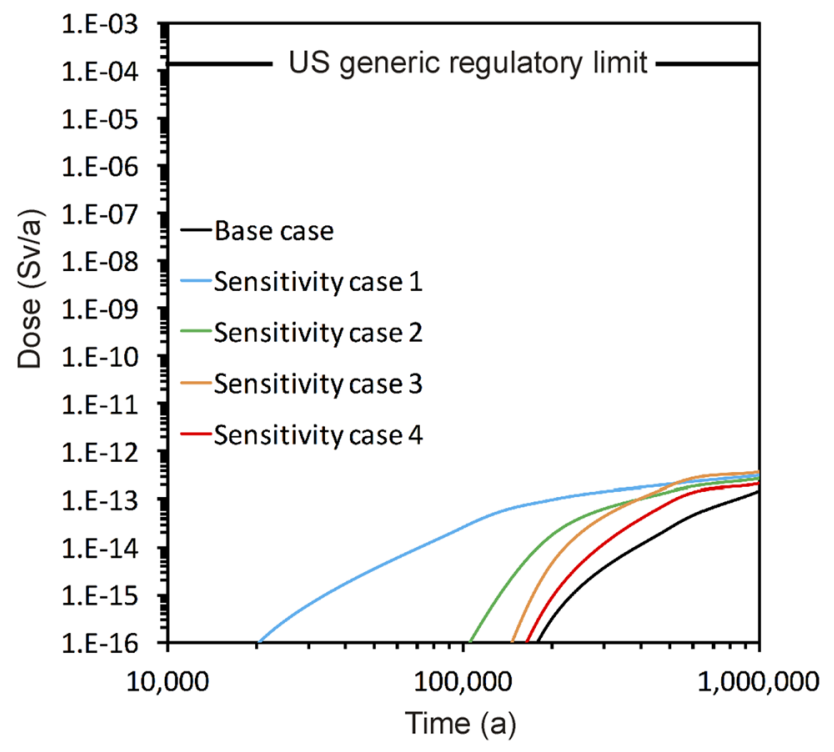

Fig. 9 Peak radioactive dose (Sv/a) of the second topmost layer of the CRB model. The base case refers to fixed water-level and one defective canister. The sensitivity case 1 refers to base-case permeabilities multiplied by 10 as well as fixed water-level, base-case repository depth and 1 defective canister. The sensitivity case 2 refers to basecase repository depth decreased by $200 \mathrm{~m}$ as well as base-case permeabilities, fixed water-level and 1 defective canister. The sensitivity case 3 refers to 10 defective canisters as well as fixed water-level, base-case repository depth and base-case permeabilities. The sensitivity case 4 refers to transient water-level (increase of the hydraulic gradient by a factor of 1.33 in the simulation year 50,000) as well as base-case permeabilities, base-case repository depth and 1 defective canister

The peak doses are the relevant parameters for the various release paths (Figs. 8, 9). At the end of the simulation period, the peak doses are far below the US generic regulatory limit (0.15 mS/a; GAO 2000) or the limit for Yucca Mountain, USA $(0.15 \mathrm{mSv} / \mathrm{a}<10,000$ years and $1 \mathrm{mSv} / \mathrm{a}>10,000$ years; NRC 2014).

Note that these low doses are calculated for an error scenario, e.g., production defects in the waste container or emplacement errors. In the standard scenario, a coppershielded waste container emplaced in a bentonite buffer with admixtures of hematite $\left(\mathrm{Fe}_{2} \mathrm{O}_{3}\right)$ should not release any radionuclides to the far-field environment. Native copper in average CRB groundwater in the presence of hematite is thermodynamically stable (Fig. 10) or, at least, close to thermodynamic equilibrium. Even if the copper shell is corroded by aqueous sulphide diffusing through the bentonite barrier, the corrosion rates will be extremely low (Schwartz 2018). Thus, the lifetime of a copper-shielded waste container is far beyond the 1 million years envisaged for the CRB repository.

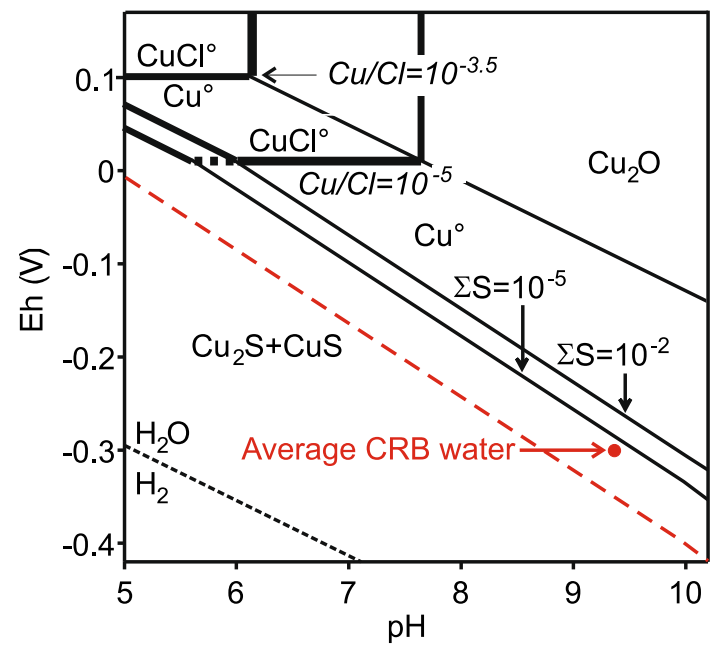

Fig. 10 Eh-pH diagram for the system $\mathrm{Cu}-(\mathrm{Fe})-\mathrm{S}-\mathrm{Cl}-\mathrm{O}-\mathrm{H}$ at $25{ }^{\circ} \mathrm{C}$ and $0.1 \mathrm{MPa}$. The thermodynamic data are calculated with the SUPCRT92 program (Johnson et al. 1992) except for $\mathrm{CuCl}^{0}$ (Xiao et al. 1998) and $\mathrm{FeSO}_{4}$ (c) (Hemingway et al. 2002). Two types of $\mathrm{Cu}^{0}$ $\mathrm{Cu}_{2} \mathrm{~S}$ boundaries are shown: the black lines refer to the Fe-free system with $\Sigma S$ of $10^{-2}$ and $10^{-5}$; the red interrupted line shows the limit of the $\mathrm{Cu}^{0}$ stability field for $\Sigma S=10^{-5}$ in the presence of hematite and $\mathrm{FeSO}_{4}(\mathrm{c})$

\section{Sensitivity tests}

The sensitivity tests address the greatest uncertainties in a performance assessment:

- permeability in regions with undetected vertical fractures;

- location of failed waste containers;

- number of failed waste containers;

- climate change and associated sea-level lowering.

The interiors of the basalt flows (colonnade/entablature) have an extremely low permeability, the median being $10^{-20} \mathrm{~m}^{2}$. The base case uses the maximum recorded value of $10^{-17} \mathrm{~m}^{2}$. It is possible that this assumption is not conservative enough. To capture the effect of undocumented vertical fractures, the first sensitivity case has all permeabilities increased by one order of magnitude. The second sensitivity test considers the decrease of the repository depth from 1100 to $900 \mathrm{~m}$. The third sensitivity test considers the increase of the number of defective canisters form one (base case) to ten.

All the above sensitivity cases have in common that the ratio between base-case values, on the one hand, and sensitivity-case values, on the other hand, decrease with time. In other words, the peak dose of the pessimistic sensitivity cases tends to converge toward that of the base case (Figs. 8, 9 ). Of course, the areal extent of the contaminant plume for the sensitivity case with ten defective canisters is much 
larger than that for the cases with only one defective canister (Fig. 8).

Introducing transient water-level conditions has a small effect. An increase in the hydraulic gradient by a factor of 1.33 in the year 50,000, simulating sea-level lowering, results in a maximum increase in the peak radioactive dose by a factor of approximately 3 .

Except for the speculative high-permeability case, the contaminant travel times are extremely long. Hardly any contaminant would come near the potentiometric surface before 100,000 years when field-test supported permeabilities are used for the calculations. This is in perfect agreement with groundwater age modelling. The deep CRB groundwater is very old, at least 100,000 years according to helium data (Reidel et al. 2002).

\section{Conclusions and discussion}

Most of the countries that produce high-level nuclear waste have the option to choose between granite and clay when looking for a disposal site. Some have the additional alternative of a basalt repository such as the USA.

In terms of heat conductivity, a quartz-poor rock such as continental flood basalt or clay has a disadvantage relative to a quartz-rich rock such as granite. The bentonite buffer around a waste container emplaced in basalt or clay is heated to higher temperatures than the buffer in a granitic environment. Since most high-level waste producing countries postpone the waste disposal into the distant future, the heat issue will become less important. For example, the heat output of 50-year-old waste would decrease to half of its original value within 40 years.

In terms of groundwater salinity, continental flood basalt has an advantage over clastic sedimentary rock such as clay. The same is true with respect to granite when fractures allow the intrusion of basinal brines. Salinity is critical, because high salt concentrations reduce the corrosion resistance of the copper shell around the waste container (Schwartz 1996, 2008).

In terms of vertical permeability, continental flood basalt has an advantage over granite with near-vertical fractures. The possibilities to offset the disadvantage for granite by increasing the repository depth are limited by the salinity gradient of granite groundwater.

For groundwater $\mathrm{pH}$, a general statement is not possible. The only deep basalt groundwater with sufficient data is the CRB groundwater. The high $\mathrm{pH}$, which averages 9.4 in the Grande Ronde Basalt Formation, would allow the copper shell around the waste container to be at or near thermodynamic equilibrium. The prerequisite is a sulphide-free bentonite buffer with admixtures of hematite $\left(\mathrm{Fe}_{2} \mathrm{O}_{3}\right)$. Even though the reason for the high $\mathrm{pH}$ is not fully understood, the CRB data justify to investigate deep basalt groundwater in other parts of the world.

Open Access This article is distributed under the terms of the Creative Commons Attribution 4.0 International License (http://creativeco mmons.org/licenses/by/4.0/), which permits unrestricted use, distribution, and reproduction in any medium, provided you give appropriate credit to the original author(s) and the source, provide a link to the Creative Commons license, and indicate if changes were made.

\section{References}

DOE (1982) Site characterization report for the Basalt Waste Isolation Project. US Department of Energy (DOE) DOE/RL 82-3, Volume I and Volume II

DOE (1988) Site characterization plan. US Department of Energy (DOE) DOE/RW-0164

DOE (2004) Nuclear Waste Policy as Amended. US Department of Energy

DOE (2007a) Initial radionuclide inventories. US Department of Energy (DOE) DOC.20070801.0001

DOE (2007b) Biosphere model report. US Department of Energy (DOE) DOC.20070830.0007

DOE (2008a) Multiscale thermohydrologic model. US Department of Energy (DOE) DOC.20080201.0003

DOE (2008b) Total system performance assessment model/analysis for the license application addendum 01 volume III. US Department of Energy (DOE) MDL-WIS-PA-000005 REV00 AD01

Duguid JO, Kowall SJ (1981) Review of geologic and hydrologic issues related to waste isolation in Columbia River Basalts. Technical Report, Office of National Waste Terminal Storage Integration, Battelle Memorial Institute, Columbus

Finsterle S (2000) iTOUGH2 user's guide. Earth Sciences Division, Lawrence Berkeley National Laboratory, University of California, Berkeley

GAO (2000) Radiation standards. US General Accounting Office (GAO) GAO/RCED-00-152

Hemingway BS, Seal RR, Chou IM (2002) Thermodynamic data for modeling acid mine drainage problems: compilation and estimation for selected soluble iron-sulfate minerals. US Geological Survey Open File Report 02-161

Johnson JW, Oelkers EH, Helgeson HC (1992) SUPCRT92: a software package for calculating the standard molal thermodynamic properties of minerals, gases, aqueous species and reactions from 1 to 5000 bar and 0 to $1000^{\circ} \mathrm{C}$. Comput Geosci 18:899-947

Lindgren M, Lindström F (1999) SR 97 Radionuclide transport calculations. SKB Technical Report TR-99-23, Stockholm

Lutton JM, Brehm WF, Maffei HP, Rivera CL, Anantatmula RP (1986) General corrosion studies of candidate container materials for the Basalt Waste Isolation Project. In: Burkholder HC (ed) High-level nuclear waste disposal. Batelle Press, Richland, pp 563-572

NRC (2014) Safety evaluation report related to disposal of high-level radioactive wastes in a geologic repository at Yucca Mountain, Nevada, vol 3, Repository safety after permanent closure. US Nuclear Regulatory Commission (NRC) NUREG-1949

Pan L (2007) WINGRIDDER version 3.0. Lawrence Berkeley National Laboratory, University of California, Berkeley

Pruess K, Oldenburg C, Moridis G (1999) TOUGH2 user's guide, version 2.0. Earth Sciences Division, Lawrence Berkeley National Laboratory, University of California, Berkeley 
Reidel SP, Johnson VG, Spane FA (2002) Natural gas storage in basalt aquifers of the Columbia Basin, Pacific Northwest USA: a guide to site characterization. PNNL-13962, Pacific Northwest National Laboratory, Richland

Salter PF, Jacobs GK (1982) Evaluation of radionuclide transport: effect of radionuclide sorption and solubility. In: Lutze W (ed) Scientific basis for radioactive waste management V. Elsevier, Amsterdam, pp 801-810

Schwartz MO (1996) Native copper deposits and the disposal of highlevel waste. Int Geol Rev 38:33-41

Schwartz MO (2008) High-level waste disposal, ethics and thermodynamics. Environ Geol 54:1485-1488

Schwartz MO (2018) The new Wallula $\mathrm{CO}_{2}$ project may revive the old Columbia River Basalt (western USA) nuclear-waste repository project. Hydrogeol J 26:3-6

SKB (2006) Long-term safety for KBS-3 repositories at Forsmark and Laxemar-a first evaluation. SKB Technical Report TR-06-09, Stockholm

Whiteman KJ, Vaccaro JJ, Gonthier JB, Bauer HH (1994) The hydrogeologic framework and geochemistry of the Columbia Plateau aquifer system, Washington, Oregon, and Idaho. US Geological Survey Professional Paper 1413-B

Xiao X, Gammons CH, Williams-Jones AE (1998) Experimental study of copper(I) chloride complexing in hydrothermal solutions at 40 to $300{ }^{\circ} \mathrm{C}$ and saturated vapor pressure. Geochim Cosmochim Acta 62:2949-2964

Xu T, Sonnenthal E, Spycher N, Zheng L (2014) TOUGHREACT V3.0-OMP Reference manual: a parallel simulation program for non-isothermal multiphase geochemical reactive transport. Earth Sciences Division, Lawrence Berkeley National Laboratory, University of California, Berkeley

Zhang K, Wu YS, Pruess K (2008) User's guide for TOUGH2-MP-a massively parallel version of the TOUGH 2 code. Report LBNL315E. Earth Sciences Division. Lawrence Berkeley National Laboratory, University of California, Berkeley

Zyvoloski GA, Robinson BA, Dash ZV, Kelkar S, Viswanathan HS, Pawar RJ, Stauffer PH (2011) Software users manual (UM) for the FEHM application version 3.1-3X. Los Alamos National Laboratory, Los Alamos 